УДК 631.162:338.

\title{
УПРАВЛІННЯ ВИРОБНИЦТВОМ АГРАРНОЇ ПРОДУКЦІї: СТАН I ТЕНДЕНЦІї РОЗВИТКУ
}

\section{MANAGEMENT OF AGRICULTURAL PRODUCTION: STATUS AND DEVELOPMENT TRENDS}

\author{
Шульський Микола Григорович \\ доктор економічних наук, професор, \\ ORCID: https://orcid.org/0000-0003-4790-3904 \\ Львівський національний університет ветеринарної медицини та біотехнологій \\ імені С.3. Гжицького \\ Смолинець Ігор Богданович \\ кандидат економічних наук, доцент, \\ ORCID: https://orcid.org/0000-0002-2896-3699 \\ Львівський національний університет ветеринарної медицини та біотехнологій \\ імені С.3. Гжицького
}

\author{
Shulskyi Mykola, Smolynets Ihor \\ Stepan Gzhytskyi National University of \\ Veterinary Medicine and Biotechnologies Lviv
}

\begin{abstract}
У статті проведено дослідження стану і тенденції розвитку управління виробництвом агарної продукції господарськими формуваннями Львівщини. В основу досліджень покладено матеріали статистичних органів, в яких відображено основні показники сільськогосподарського виробництва. При цьому особливу увагу сконцентровано на показниках виробництва аграрної продукції як у грошовій, так і в натуральних формах оцінки. Дослідження проведено від загального до конкретного. Загальні показники виробництва сільськогосподарської продукції господарськими аграрними формами господарювання представлені у грошовій фрормі. Для цього використано діючі постійні ціни на продукцію сільського господарства, що діяли у 2016 р. Такий підхід обумовлений тим, щоб уникнути негативного впливу цінового фактору на обсяги виробництва продукції. Цей методичний підхід дозволив об'єктивного оцінити обсяги виробництва аграрної продукції протягом 2010-2019 рр. як у загальних виразах, так і в розрізі окремих галузях. При цьому дослідженнями встановлено, що в структурі продукції сільського господарства більшу питому вагу складає продукція рослинництва, ніж тваринництва. I це є характерним як для аграрних підприємств (крупні фрорми господарювання), так і для дрібних господарств (господарства населення). При цьому характерним є те, що хоча підприємства збільшують обсяги виробництва продукції швидшими темпами, однак вони ще не досягли і не перевершили обсягів продукування продукції господарствами населення. Статистичні органи Львівщини значну увагу приділили показникам виробництва аграрної продукції в натуральній оцінці, починаючи з 1990 і закінчуючи 2019 р. Ця інформація є цінна для наших досліджень тим, що дозволяє оцінити виробництво продукції аграрними фрормуваннями у дореформений і післяреформений періоди. При цьому виробництво продукції рослинництва має тверду тенденцію до зростання, за виключенням цукрового буряка. Виробництво тваринницької продукції має чіткіше виражену строкатість. При цьому позитивними наслідками характеризується виробництво продукції птахівництва як підприємствами, так і господарствами населення.
\end{abstract}

Ключові слова: управління, виробництво, тенденції, сільськогосподарська продукція.

В статье проведено исследование состояния и тенденции развития управления производством аграрной продукции хозяйственными формированиями Львовщины. В основу исследований положены материалы статистических органов, в которых отражены основные показатели сельскохозяйственного производства. При этом особое внимание сконцентрировано на показателях производства аграрной продукции как в денежной, так и в натуральных формах оценки. Исследование проведено от общего к частному. Общие показатели производства сельскохозяйственной продукции хозяйственными аграрными формами хозяйствования представлены в денежной форме. Для этого использовано действующие постоянные цены на продукцию сельского хозяйства, которые действовали в 2016 Такой подход обусловлен тем, чтобы не создавать помех ценового 
фрактора на объем производства продукции. Этот методический подход позволил объективного оценить объемы производства аграрной продукции на протяжении 2010-2019 гг. Как в общих выражениях, так и в разрезе отдельных отраслях. При этом исследованиями установлено, что в структуре продукции сельского хозяйства больший удельный вес составляет продукция растениеводства, чем животноводства. И это характерно как для аграрных предприятий (крупные фрормы хозяйствования), так и для мелких хозяйств (хозяйства населения). При этом характерно, что хотя предприятия увеличивают объемы производства продукции более быстрыми темпами, однако они еще не достигли и не превзошли объемов выработки продукции хозяйствами населения. Статистические органы Львовщины значительное внимание уделили показателям производства аграрной продукции в натуральной оценке, начиная с 1990 и заканчивая 2019 Эта информация ценна для наших исследований тем, что позволяет оценить производство продукции аграрными формированиями в дореформенный и пореформенный периоды. При этом производство продукции растениеводства имеет твердую тенденцию к росту, исключая сахарной свеклы. Производство животноводческой продукции имеет четко выраженную пестроту. При этом положительными последствиями характеризуется производство продукции птицеводства как предприятиями, так и хозяйствами населения.

Ключевые слова: управление, производство, тенденции, сельскохозяйственная продукция.

The article examines the state and trends of agar production management by economic formations of Lviv region. The research is based on the materials of statistical bodies, which reflect the main indicators of agricultural production. At the same time, special attention is paid to the indicators of agricultural production in both monetary and in-kind forms of evaluation. The study was conducted from general to specific. General indicators of agricultural production by economic agrarian forms of management are presented in monetary form. For this purpose, the current constant prices for agricultural products, which were in force in 2016, were used. This approach is to avoid the negative impact of the price factor on production volumes. This methodological approach allowed to objectively assess the volume of agricultural production during 2010-2019, both in general terms and in terms of individual industries. At the same time, research has shown that in the structure of agricultural products a larger share is crop production than livestock. And this is typical for both agricultural enterprises (large forms of management) and small farms (households). It is characteristic that although enterprises are increasing production volumes at a faster pace, they have not yet reached and have not exceeded the production volumes of households. Statistical authorities of Lviv region have paid considerable attention to the indicators of agricultural production in kind, starting from 1990 and ending in 2019. This information is valuable for our research because it allows us to assess the production of agricultural holdings in the pre-reform and post-reform periods. At the same time, crop production has a solid upward trend, with the exception of sugar beet. Livestock production has a more pronounced variety. At the same time, the production of poultry products by both enterprises and households is characterized by positive consequences. Thus, in the final conclusions it can be stated that in the agricultural production of Lviv region there have been positive trends. At the same time, large positive formations (enterprises) have achieved significant positive changes in the agrarian sphere, which are objective and natural processes of development. As for small forms of management, they should not be opposed to large farms, but the most rational to combine their interests and opportunities.

Keywords: management, production, trends, agricultural products.

Вступ. Аграрна сорера управління виробництвом, як і будь-яка сорера матеріального виробництва, характеризується цілим комплексом різноманітних показників, важливими серед яких є показники валового виробництва продукції. Саме ці аспекти спонукали обрання даної теми досліджень. У сільському господарстві виробляється значна кількість продукції, яка призначається для забезпечення людства продуктами харчування і тому продукування цієї продукції $€$ надто важливим як для кожної країни, так і її окремих складових. Управління виробництвом сільськогосподарської продукції займаються різні аграрні виробники, які згруповані у дві великі групи: аграрні підприємства (крупні господарські формування) і господарства населення (дрібні форми господарювання). Саме у розрізі цих господарських структур і передбачено провести дослідження.
Важливою складовою у проведенні досліджень за обраною темою є часові фрактори, які в даному випадку вимірюються господарськими роками. Нами обрані періоди 1990-2019 рр., що дають можливість прослідкувати, як змінювались показники виробництва продукції як у дореформений (1990р.), так і пореформений період (після 1990 р.). При цьому, варто зауважити, що нами дослідження результатів діяльності крупних аграрних підприємств і дрібних господарств населення розглянуто в їх діалектичному поєднанні, взаємозв'язку і доповненні в їх фрункціонуванні, а не в протилежних аспектах. Все це в комплексі, на наше переконання, дає можливість більш глибше проникнути у ссрери більш повнішого використання наявних можливостей і ресурсів у збільшенні виробництва продукції аграрними фрормуваннями АПК.

Постановка проблеми. У процесах проведення досліджень використані матеріали ста- 
тистичних органів, результати дослідження вітчизняних вчених тощо. Щодо методів дослідження: примінено загальнонаукові та спеціальні методи дослідження. Це, перш за все: діалектичний, синтезу, індукції та дедукції, структурно-орункціонального аналізу, системного підходу, абстрагування, порівняння, діалогового підходу та ін.. Все це в комплексі дозволило виконати поставлені завдання і досягти передбаченої мети.

Аналіз останніх досліджень. Дослідженням управління виробництва продукції сільського господарства аграрними фрормуваннями як на державному, так і регіональному рівнях займалися ціла плеяда як видатних, так і на сьогоднішній день маловідомих дослідників. Ці проблеми висвітлені у працях: П.Т. Саблука, С.В. Мочерного, В.Я. МеселяВеселяка, М.М. Федорова, М.В. Зубця, М.Г. Шульського, Я.П. Березівського, І.Б. Смолинця та ін. Незважаючи на вищесказане слід відмітити, що кожен господарський рік вносить певні і відчутні зміни у ведення сільськогосподарського виробництва аграрними фрормуваннями. І ці зміни і переміни слід детально та всебічно досліджувати, а одержані результати необхідно використовувати для збільшення обсягів виробництва аграрної продукції.

Мета та завдання дослідження. Метою дослідження є детальний аналіз стану управління виробництвом аграрної продукції господарськими формуваннями Львівщини. На основі одержаних результатів виявити основні тенденції у виробничій сорері, на основі яких зробити певні узагальнення і висновки. Розроблені завдання досліджень підпорядковані досягненням поставленої мети.

Результати та їх обговорення. Будь-який суб'єкт господарювання, у будь-якій сорері діяльності, характеризується, перш за все, обсягами продукції, що він виробляє. І це, до речі відмітити, було характерним у минулому, не втратило свого значення в умовах сьогодення і буде важливим показником на майбутнє.

Приступаючи до досліджень того чи іншого явища у різних сорерах суспільних відносин, кожен науковець використовує ті чи інші терміни, які $€$ характерним для галузі, яку він досліджує. І3-за цих обставин, безумовно, виникає об'єктивна необхідність з'ясувати у доступних та зрозумілих формах до тих осіб, для яких представляє інтерес матеріал тієї чи тієї публікації. Враховуючи ті архіважливі складові будь-якого дослідження, нами проведено відповідні узагальнення сутті тих чи тих основних термінів, які передбачено використати при виконанні основних завдань у підготовці даної статті. Безумовно, слід взяти до уваги, що серед науковців існують різні розуміння, твердження та інтерпретація понять розвитку тих чи інших термінів. І це, досить зауважити, є цілком нормальне явище в процесах дослідження розвитку будь-якого суспільного явища: адже скільки вчених цих чи інших напрямів, стільки різних поглядів. І це слід враховувати, що нами і було зроблено при підготовці даної статті. Підтвердженням сказаного може бути інформація, що наведена в таблиці 1, яка сконцентрована на переліку термінів, що використовуються при підготовці даної публікації та з'ясування їх сутті у трактуванні статистичними органами.

Зібрана і певним чином оброблена інфрормація представлена у згаданій раніше таблиці 1. Отож, перш за все, звернемо увагу на продукцію сільського господарства, в склад якої входить все те, що виробляється як у рослинництві, так і тваринництві та оцінено в постійних цінах 2016 р. (відповідь на питання 1-3 таблиці 1). Представлення виробленої аграрної продукції у постійних цінах 2016 р. дозволяє врахувати весь обсяг виробленої продукції, позбавляючись впливу цінових чинників для її обсяги, які, до речі нагадати , в значній мірі залежать від впливу зовнішніх фракторів, а не безпосередніх виробників. Саме такий методичний підхід дозволяє об'єктивно і комплексно підійти до оцінки діяльності аграрних виробників на протязі певного періоду їх розвитку.

Щодо суб'єктів господарювання. 3 цього приводу відзначимо, що для наших досліджень обрані сільськогосподарські підприємства та господарства населення. Їх склад представлений у відповідях на питання 4-7 таблиці 1. Погоджуючись із вищенаведеними твердженнями, все-таки ми вважаємо, що віднесення фермерських господарств до складу підприємств $€$ неправомірним. Свою позицію ми обґрунтовуємо тим, що кожен суб'єкт господарювання повинен окремо характеризуватися щодо наслідків своєї діяльності, а не розчинятися в масі інших підприємств. Це особливо відноситься до фермерської форми ведення аграрного виробництва. Тим більше, що це нова фрорма господарювання у вітчизняному сільському господарстві, яку слід опробовувати системно, комплексно та деталізовано.

Для дослідження цифрової інфрормації за обраною темою нами використані окремі роки на протязі 2010-2019 рр. Оброблені певним чином дані представлені в таблиці 2. Детальний аналіз дозволяє констатувати наступне: 
Суть основних термінів в оцінці статистичних органів

Таблиця 1*

\begin{tabular}{|c|c|c|}
\hline $\begin{array}{l}\text { № } \\
\text { ח/ח }\end{array}$ & $\begin{array}{l}\text { Перелік основних } \\
\text { термінів }\end{array}$ & Їх суть в оцінці статистичних органів \\
\hline 1 & $\begin{array}{l}\text { Продукція сільського } \\
\text { господарства (у постійних } \\
\text { цінах) }\end{array}$ & $\begin{array}{l}\text { Вартість продукції рослинництва та тваринництва, } \\
\text { отриманої внаслідок вирощування сільськогосподарських } \\
\text { культур та використання сільськогосподарських тварин }\end{array}$ \\
\hline 2. & $\begin{array}{l}\text { Що ще входить в обсяги } \\
\text { продукції сільського } \\
\text { господарства? }\end{array}$ & $\begin{array}{l}\text { Також обсяг незавершеного виробництва у рослинництві, } \\
\text { обсяг вирощування молодих багаторічних насаджень за } \\
\text { рік та обсяг вирощування сільськогосподарських тварин } \\
\text { (приплід, приріст живої маси) }\end{array}$ \\
\hline 3. & Постійні ціни & $\begin{array}{l}\text { Середньозважені ціни року, прийнятого за основу для } \\
\text { порівняння }\end{array}$ \\
\hline 4. & Підприємство & $\begin{array}{l}\text { Суб'єкт господарювання, який має право юридичної особи, } \\
\text { що здійснює систематичну виробничу діяльність у галузі } \\
\text { сільського господарства }\end{array}$ \\
\hline 5. & $\begin{array}{l}\text { Що ще включають } \\
\text { до складу підприємств? }\end{array}$ & $\begin{array}{l}\text { До складу підприємств включають також фрермерські } \\
\text { господарства. }\end{array}$ \\
\hline 6. & Господарства населення & $\begin{array}{l}\text { Домогосподарства, що здійснюють сільськогосподарську } \\
\text { діяльність, як з метою самозабезпечення продуктами } \\
\text { харчування, так і з метою виробництва товарної } \\
\text { сільськогосподарської продукції }\end{array}$ \\
\hline 7. & $\begin{array}{l}\text { Що ще включає категорія } \\
\text { домогосподарств? }\end{array}$ & $\begin{array}{l}\text { Ця категорія включає домогосподарства у сільській } \\
\text { місцевості, міських населених пунктах (включаючи сади та } \\
\text { городи), а також фрізичних осіб-суб'єктів підприємницької } \\
\text { діяльності, які проводять свою діяльність у галузі } \\
\text { сільського господарства без створення юридичної особи }\end{array}$ \\
\hline
\end{tabular}

Примітка:* тут і на далі використано Матеріали статистичного щорічника Львівської області [7]

Таблиця 2

Структура продукції сільського господарства за категоріями, млн. грн. господарств у Львівській області, у постійних цінах 2016 р.

\begin{tabular}{|l|c|c|c|c|c|c|c|c|c|}
\hline \multirow{2}{*}{ Покизники } & \multicolumn{2}{|c|}{$\mathbf{2 0 1 0}$} & $\mathbf{2 0 1 5}$ & $\mathbf{2 0 1 8}$ & \multicolumn{2}{c|}{$\mathbf{2 0 1 9}$} & $\mathbf{2 0 1 9}$ у \% до \\
\cline { 2 - 9 } & млн. грн & \% & млн. грн & млн. грн & млн. грн & \% & $\mathbf{2 0 1 0}$ & $\mathbf{2 0 1 8}$ \\
\hline \multicolumn{7}{|c|}{ Господарства всіх категорій } \\
\hline $\begin{array}{l}\text { Усього } \\
\text { у тому числі продукція: }\end{array}$ & 16563,4 & 100 & 20937,4 & 22818,7 & 23004,4 & 100,0 & 138,9 & 1087,1 \\
\hline рослинництва & 9347,6 & 56,4 & 13198,5 & 15522,3 & 15967,9 & 69,4 & 170,8 & 128,8 \\
\hline тваринництва & 7215,8 & 43,6 & 7038,9 & 7296,4 & 7036,5 & 30,6 & 87,5 & 96,4 \\
\hline \multicolumn{7}{|c|}{ Підприємства } \\
\hline $\begin{array}{l}\text { Усього } \\
\text { у тому числі продукція: }\end{array}$ & 5095,6 & 30,8 & 8269,2 & 11103,0 & 11063,3 & 48,1 & 217,2 & 99,6 \\
\hline рослинництва & 3318,7 & 20,0 & 6232,5 & 8405,4 & 8480,6 & 36,9 & 255,5 & 100,9 \\
\hline тваринництва & 1776,9 & 10,8 & 2036,7 & 2697,6 & 2582,7 & 11,2 & 145,6 & 95,7 \\
\hline \multicolumn{7}{|c|}{ Господарства населення } \\
\hline $\begin{array}{l}\text { Усього } \\
\text { у тому числі продукція: }\end{array}$ & 11467,8 & 69,2 & 11966,2 & 11715,7 & 11941,1 & 51,9 & 104,1 & 101,9 \\
\hline рослинництва & 6028,9 & 36,4 & 6966,0 & 7116,9 & 7487,3 & 32,5 & 124,2 & 105,2 \\
\hline тваринництва & 5438,9 & 32,8 & 5002,2 & 4598,8 & 4453,8 & 19,4 & 81,9 & 96,8 \\
\hline
\end{tabular}


- загальні обсяги виробленої продукції мають тверду тенденцію до збільшення. Так, скажімо, коли порівнювати дані за 2019 р. 3 показниками за 2010 р., то спостерігається збільшення виробництва продукції як всіма категоріями господарств (на 38,9\%), так і в розрізі окремих категорій (господарства населення збільшили лише на 4,1\%, однак підприємства на 70,8\%);

- у розрізі окремих галузей тенденції дещо відмінні. Насамперед це відноситься до виробництва продукції тваринництва, обсяги якої зменшилися як у всіх категоріях господарств, так і в господарствах населення. Виключення становлять підприємства, які збільшили обсяги виробництва продукції у 2019 р. проти рівня роботи 2010 р. на 45,6 \% Дані порівняння 2019 р. з 2018 р. показують, що відбулись деякі зміни, однак тенденції не змінились;

- неабиякий інтерес представляють показники структури виробництва аграрної продукції у розрізі як окремих категорій господарств, так і в загальному виразі всіма господарюючими суб'єктами. За всі наведені роки виробництво рослинницької продукції має тверду тенденцію до збільшення, а тваринницької до зменшення.

Представлені вище результати досліджень обсягів виробництва аграрної продукції господарськими формуваннями Львівщини відображені у вартісних показниках у галузевому розрізі. Проте для науки і практики важливо досліджувати обсяги виробництва продукції в натуральних вимірах. При цьому важливо відзначити, що людина в результаті своєї управлінською взаємодії з природою одержує конкретні види сільськогосподарської продукції в натуральних показниках, а вартісну ії оцінку вона робить самостійно, поза, так би мовити, природньо-виробничими процесами.

Враховуючи важливість вищесказаного, виникає об'єктивна необхідність у проведенні досліджень виробництва аграрної продукції в натуральних показниках в розрізі окремих фрорм господарювання. Оброблена певним чином інформація щодо виробництва продукції рослинництва представлена в таблиці 3.

Для такого дослідження статистичними органами Львівщини у своїх виданнях наведена обширна цифрова інфрормація протягом тривалого періоду 1990-2019 рр. Тобто, охо-

Таблиця 3

Виробництво продукції рослинництва за категоріями господарств Львівщини, тис. т

\begin{tabular}{|c|c|c|c|c|c|c|c|c|}
\hline \multirow{2}{*}{$\overbrace{\text { Показники }}^{\text {Роки }}$} & \multirow{2}{*}{1990} & \multirow{2}{*}{2000} & \multirow{2}{*}{2010} & \multirow{2}{*}{2015} & \multirow{2}{*}{2018} & \multirow{2}{*}{2019} & \multicolumn{2}{|c|}{2019 у \% до } \\
\hline & & & & & & & 1900 & 2018 \\
\hline \multicolumn{9}{|c|}{ Господарства всіх категорій } \\
\hline $\begin{array}{l}\text { /льтури зернові } \\
\text { з зерновобобові }\end{array}$ & 1009,7 & 481,4 & 622,6 & 136 & 1440,0 & 643,7 & 162,5 & 14,1 \\
\hline $\begin{array}{l}\text { Буряк цукровий } \\
\text { фабричний }\end{array}$ & 1597,4 & 400,6 & 529,5 & 0 & & & 38 & 1 \\
\hline Ріпак і кольза & 21,4 & 14,2 & 97,2 & 14 & & & 2,1 & 9 \\
\hline Картопля & 1331,8 & 1510,3 & 1258,8 & & & & & 6 \\
\hline Культури овочеві & 18 & 268,6 & & & & & & 138,3 \\
\hline одові & 112,6 & 90,5 & 90,1 & 106,8 & 137,5 & 6 &, 9 & 89,2 \\
\hline \multicolumn{9}{|c|}{ Підприємства та господарства населення } \\
\hline $\begin{array}{l}\text { Культури зернові } \\
\text { та зерновобобові }\end{array}$ & $\frac{990,8^{\star}}{18,9^{\star \star}}$ & $\frac{260,0}{221,4}$ & $\frac{324,0}{298,6}$ & & & $\frac{1204,0}{439,7}$ & $2 \frac{121,5}{23,3 \text { раза }}$ & $\frac{117,5}{105,8}$ \\
\hline $\begin{array}{l}\text { Буряк цукровий } \\
\text { фрабричний }\end{array}$ & $\frac{1597,4}{-}$ & $\frac{190,6}{210,0}$ & $\frac{496,9}{32,6}$ & $\frac{573,3}{9,7}$ & $\frac{660,2}{11,7}$ & $\frac{619,0}{-}$ & $\frac{38,8}{-}$ & $\frac{93,7}{-}$ \\
\hline Ріпа & $\frac{21,4}{-}$ & 14,2 & $\frac{97,2}{-}$ & $\frac{141,2}{-}$ & $\frac{207,5}{-}$ & $\frac{184,5}{-}$ & $\frac{862,1}{-}$ & $\frac{88,9}{-}$ \\
\hline Картопля & $\frac{234,2}{1097,6}$ & $\frac{17,0}{1493,3}$ & $\frac{48,9}{1209,9}$ & $\frac{46,3}{1576,2}$ & $\frac{50,7}{1647,5}$ & $\frac{50,0}{1522,9}$ & $\frac{21,3}{138,7}$ & $\frac{98,6}{92,4}$ \\
\hline Культури овочеві & $\frac{139,4}{42,4}$ & $\frac{12,1}{256,5}$ & $\frac{19,2}{392,7}$ & $\frac{35,3}{448,2}$ & $\frac{25,8}{487,0}$ & $\frac{29,8}{679,3}$ & $\frac{21,4}{1602,1}$ & $\frac{115,2}{139,5}$ \\
\hline $\begin{array}{l}\text { Культури плодові } \\
\text { та ягідні }\end{array}$ & $\frac{2,6}{110,0}$ & $\frac{1,2}{89,3}$ & $\frac{0,8}{89,3}$ & $\frac{10,1}{96,7}$ & $\frac{20,7}{116,8}$ & $\frac{21,7}{100,9}$ & $\frac{834,6}{91,7}$ & $\frac{104,8}{86,4}$ \\
\hline
\end{tabular}

Примітки: * чисельник - підприємства; **знаменник - господарства населення. 
плено дві системи господарювання, а саме: кінець соціалістичної (1990р.) і початок перехідної економіки (2000 р. і наступні роки).

Ми у цій публікації не будемо вглиблюватися в особливості здійснення цих глобальних процесів, що відбулись у кінці XX і початку XXI століть в економіці аграрних перетворень. Ці кардинальні перетворення вимагають проведення окремих повномасштабних досліджень. І вони, до речі нагадати, проводились в минулому, проводяться зараз і будуть проводитися в майбутньому. Така діалектика оцінки розвитку форм господарювання та їх оцінка.

Дещо конкретизуємо аналіз цифрової інфрормації щодо динаміки виробництва продукції рослинництва як у розрізі окремих категорій господарств, з одного боку, так і 3 виділенням конкретних видів рослинницької продукції, з іншого. Порівняння даних за 2019 р. $з$ даними 1990 р. дає підстави стверджувати, що в цей проміжок часу відбулись значні позитивні зміни в обсягах збільшення окремих видів продукції рослинництва, за виключення виробництва цукрових буряків фрабричних, де допущено значне зменшення обсягів їх продукування (у 2019 р. було вироблено всього 38,8 \% до рівня 1990 р.). Досить також нагадати, що Україна по виробництву цукру із цукрових буряків займала провідне місце в Європі. В сьогоднішніх умовах цю галузь слід відновлювати і нарощувати втрачене в період здійснення аграрних реформ. Щодо порівняння даних за 2019 р. 3 показниками 2018 р., то слід констатувати, що зростання спостерігається тільки 3 виробництва зерна $(14,1 \%)$ і овочів (38,3 \%). По всіх інших видах продукції допущено зниження. Ця порівняльна цисррова інфрормація дає підстави констатувати, що у розвитку рослинницької галузі $€$ не використані ресурси. Матеріали порівнянь 2019 р. з 2018 р. в основному підтверджують сказане вище.

Дещо відмінна циоррова інсрормації щодо розвитку тваринництва як у цілому в галузі, так і в розрізі окремих форм господарювання (табл. 4). Проведений аналіз показує, що зниження допущено майже по всіх видах тваринницької продукції, за виключенням продукції птахівництва (м'яса птиці і одержання яєць). При цьому ватро зауважити, що найбільше

Таблиця 4

Виробництво продукції тваринництва за категоріями господарств Львівщини, тис. т

\begin{tabular}{|c|c|c|c|c|c|c|c|c|}
\hline \multirow{2}{*}{ Показники } & \multirow{2}{*}{1990} & \multirow{2}{*}{2000} & \multirow{2}{*}{2010} & \multirow{2}{*}{2015} & \multirow{2}{*}{2018} & \multirow{2}{*}{2019} & \multicolumn{2}{|c|}{2019 у \% до } \\
\hline & & & & & & & 1900 & 2018 \\
\hline \multicolumn{9}{|c|}{ Господарства всіх категорій } \\
\hline $\begin{array}{l}\text { М'ясо (у забійній } \\
\text { вазі) }\end{array}$ & 180,9 & 68,4 & 115,1 & 119,9 & 131,3 & 130,0 & 71,9 & 99,0 \\
\hline $\begin{array}{l}\text { у тому числі } \\
\text { яловичина та } \\
\text { телятина }\end{array}$ & 91,2 & 34,8 & 33,1 & 27,9 & 25,1 & 24,9 & 27,3 & 99,2 \\
\hline свинина & 50,3 & 23,3 & 31,5 & 47,7 & 50,3 & 47,8 & 95,0 & 95,0 \\
\hline м'ясо птиці & 37,8 & 8,9 & 47,6 & 42,7 & 53,8 & 55,3 & 146,3 & 102,8 \\
\hline Молоко & 1083,9 & 1032,0 & 656,2 & 571,2 & 506,7 & 480,9 & 44,4 & 94,9 \\
\hline Яйця, млн. шт & 728,6 & 465,9 & 576,8 & 536,6 & 561,5 & 581,1 & 79,6 & 103,5 \\
\hline \multicolumn{9}{|c|}{ Підприємства та господарства населення } \\
\hline $\begin{array}{l}\text { М'ясо (у забійній } \\
\text { вазі) }\end{array}$ & $\frac{111,3^{\star}}{69,6^{\star \star}}$ & $\frac{6,7}{61,7}$ & $\frac{51,9}{63,2}$ & $\frac{60,6}{59,3}$ & $\frac{77,0}{54,3}$ & $\frac{76,6}{53,4}$ & $\frac{69,7}{76,7}$ & $\frac{99,5}{98,3}$ \\
\hline $\begin{array}{l}\text { у тому числі } \\
\text { яловичина та } \\
\text { телятина }\end{array}$ & $\frac{83,5}{7,7}$ & $\frac{5,7}{29,1}$ & $\frac{2,4}{30,7}$ & $\frac{3,0}{24,9}$ & $\frac{1,6}{23,5}$ & $\frac{1,5}{23,4}$ & $3 \frac{1,8}{303,9}$ & $\frac{93,8}{99,6}$ \\
\hline свинина & $\frac{10,2}{40,1}$ & $\frac{0,5}{22,8}$ & $\frac{10,7}{20,8}$ & $\frac{24,1}{23,6}$ & $\frac{30,2}{20,1}$ & $\frac{28,8}{19,0}$ & $\frac{282,4}{47,4}$ & $\frac{95,4}{94,5}$ \\
\hline м'ясо птиці & $\frac{16,8}{21,0}$ & $\frac{0,4}{8,5}$ & $\frac{38,8}{8,8}$ & $\frac{33,5}{9,2}$ & $\frac{45,2}{8,6}$ & $\frac{46,3}{9,0}$ & $\frac{275,6}{42,9}$ & $\frac{102,4}{104,7}$ \\
\hline Молоко & $\frac{588,1}{495,8}$ & $\frac{66,0}{966,0}$ & $\frac{22,9}{633,3}$ & $\frac{25,6}{545,6}$ & $\frac{28,9}{477,8}$ & $\frac{29,6}{451,3}$ & $\frac{5,0}{91,0}$ & $\frac{102,4}{94,5}$ \\
\hline Яйця, млн. шт & $\frac{357,5}{371,1}$ & $\frac{55,3}{410,6}$ & $\frac{136,0}{440,8}$ & $\frac{59,3}{477,3}$ & $\frac{56,7}{504,8}$ & $\frac{54,1}{527,0}$ & $\frac{15,1}{142,0}$ & $\frac{25,4}{104,4}$ \\
\hline
\end{tabular}

Примітки: * чисельник - підприємства; **знаменник - господарства населення. 
зниження обсягів виробництва продукції тваринництва допущено у скотарстві взагалі і її молочному скотарстві зокрема. Коли розглядати обсяги виробництва в розрізі окремих фрорм господарювання, то спостерігаються різні тенденції як у зниженні обсягів продукування окремих видів тваринницької продукції та їх скорочення.

При цьому, варто зауважити, що господарства населення характеризуються більшою стабільністю обсягів виробництва окремих видів продукції, ніж аграрні підприємства. Тобто тут чітко проявляються тенденції щодо стійкості дрібних форм господарювання (господарства населення) до проведення ресрормуючих процесів і значних обсягів скорочення виробництва крупними фрормуваннями (підприємства).

Встановивши основні тенденції щодо виробництва продукції аграрних галузей, виникає питання, які чинники обумовили такі процеси? Відповідь на поставлені питання частково міститься у вищенаведеному тексті, а деякі 3 них наведено у цій публікації. Перш за все це перехід від однієї системи господарювання (соціалістичної) до іншої (з основами ринкової економіки) завжди супроводжується дією негативних фракторів на ці процеси. Осо- бливо це чітко проявляється тоді, коли реформатори хочуть одержати позитивні результати швидко і з мінімальними затратами на їх досягнення. Це, так би мовити, глобальна причина. щодо причин, що гальмували і гальмують процеси виробництва конкретних видів продукції у кожній аграрній галузі, то вони характеризуються специфічними ознаками, що характерні для розвитку галузей. Про це ми відзначимо у висновках.

Висновки. Узагальнюючи вищесказане, можна зробити висновки проте, що в аграрному виробництві Львівщини за досліджуваний період відбулися позитивні тенденції в обсягах виробництва аграрної продукції, що $€$ наслідками управлінської діяльності і перспективи. Це по-перше. А по-друге, розвиток тваринництва характеризується негативними тенденціями в обсягах продукування продукції. Чому це відбулось так, а не інакше?

Перспективи подальших досліджень. Відповідь на ці архіскладні і архіважливі питання повинні дати подальші здійснення досліджень за обраною темою, які слід проводити 3 детальним аналізом впливу як фракторів внутрішнього, так і зовнішнього середовища 3 акцентуванням уваги на здійснення управлінських процесів.

\section{СПИСОК ВИКОРИСТАНИХ ДЖЕРЕЛ:}

1. Аграрний сектор економіки України (стан і перспективи розвитку) / [М.В. Присяжнюк, М.В. Зубець, П.Т. Саблук та ін.]; за ред. М.В. Присжнюка, М.В. Зубця, П.Т. Саблука, В.К. Збарського, В.Я. Меселя-Веселяка, М.М. Федорова. Київ : ННЦ ІАЕ, 2011. 1008 с.

2. Дорош-Кізим М.М., Дадак О.О., Гачек Т.С. Перспективи розвитку агропромислового комплексу України в умовах євроінтеграції. Науковий вісник Львівського національного університету ветеринарної медицини та біотехнологій імені С.3. Гжицького. Серія «Економічні науки». Том 19. № 76. Львів, 2017. С. 47-55.

3. Копитко В.І., Копитко О.В. Напрями розвитку овочевої продукції. Бізнес-навігатор. 2021. Випуск 1(62). C. $47-52$.

4. Мочерний С.В., Ларіна Я.С., Устенко О.А., Юрій С.І. Економічний енциклопедичний словник : У 2 т. Т. 2 I За ред. С.В. Мочерного. Львів : Світ, 2006. 568 с.

5. Смолинець І.Б. Індексний аналіз діяльності аграрних формувань Львівської області у контексті конкурентоспроможності. Збірник наук. праць Хмельницького університету управління та права. Хмельницький, 2012. C. $128-134$.

6. Смолинець І.Б. Шляхи вдосконалення окремих організаційно-правових фрорм підприємницької діяльності в аграрному секторі. Науковий вісник Львівського національного університету ветеринарної медицини та біотехнологій імені С.3. Ґжицького. Львів, 2019. Том 21. № 92. С. 60-67.

7. Статистичний щорічник Львівської області за 2019 р. Частина 1 / За ред. Світлани Зимовіної. Львів, 2020. $310 \mathrm{c}$.

8. Шульський М.Г. Аналіз співвідношення поголів'я сільськогосподарських тварин і виробництво тваринницької продукції господарствами Львівщини на стику епох. Науковий вісник Львівського національного університету ветеринарної медицини та біотехнологій імені С.З. Гжицького. Серія «Економічні науки». 2020. Том 22. № 95. Львів. С. 32-37.

9. Шульський М.Г. Аграрне виробництво у ссрерах рослинництва та стику епох: минуле, сучасне, майбутнє. Журнал Київського університету ринкових відносин «Економіка бізнес, адміністрування, право». 2017. Випуск 3. С. 183-201. 
10.Шульський М.Г. Аналіз рівня рентабельності аграрного виробництва в сільськогосподарських підприємствах Львівщини. Прикладна економіка - від теорії до практики : матеріали Міжнародної науково-практичної конфреренції. Тернопіль : ФОП Осадца Ю.В., 2017. С. 172-175.

\section{REFERENCES:}

1. Agrarian sector of the economy of Ukraine (state and prospects of development) (2011) [Ahrarnyy sektor ekonomiky Ukrayiny (stan i perspektyvy rozvytku)] [M.V. Prysyazhnyuk, M.V. Zubets', P.T. Sabluk ta in.]; za red. M.V. Pryszhnyuka, M.V. Zubtsya, P.T. Sabluka, V.K. Zbars'koho, V.Ya. Meselya-Veselyaka, M.M. Fedorova. Kyiv: NNTS IAE, $1008 \mathrm{p}$.

2. Dorosh-Kizim M.M., Dadak O.O., Gachek T.S. (2017). Prospects for the development of Ukraine's agro-industrial complex in the context of European integration [Perspektyvy rozvytku ahropromyslovoho kompleksu Ukrayiny v umovakh yevrointehratsiyi]. Scientific Bulletin of Lviv National University of Veterinary Medicine and Biotechnology named after SZ Gzhytsky, Economic Sciences Series, vol. 19, no. 76. Lviv, pp. 47-55.

3. Kopytko V.I., Kopytko O.V. (2021). Directions of development of vegetable products [Napryamy rozvytku ovochevoyi produktsiyi]. Business-navigator, issue 1(62), pp. 47-52.

4. Mocherny S.V., Larina Ya.S., Ustenko O.A., Yuriy S.I. (2006). Economic encyclopedic dictionary [Ekonomichnyy entsyklopedychnyy slovnyk]: In 2 vols. Vol. 2 / Ed. S.V. Mochernogo. Lviv: Svit, 568 p.

5. Smolynets I.B. (2012). Index analysis of the activity of agrarian formations of Lviv region in the context of competitiveness [Indeksnyy analiz diyal'nosti ahrarnykh formuvan' L'vivs'koyi oblasti u konteksti konkurentospromozhnosti]: Collection of sciences. Proceedings of Khmelnytsky University of Management and Law Khmelnytsky, pp. 128-134.

6. Smolynets I.B. (2019). Ways to improve certain organizational and legal forms of entrepreneurial activity in the agricultural sector [Shlyakhy vdoskonalennya okremykh orhanizatsiyno-pravovykh form pidpryyemnyts'koyi diyal'nosti v ahrarnomu sektori]. Scientific Bulletin of Lviv National University of Veterinary Medicine and Biotechnology named after S.Z. Gzhytsky. Lviv, vol. 21, no. 92, pp. 60-67.

7. Statistical Yearbook of Lviv region for 2019 (2020) [Statystychnyy shchorichnyk L'vivs'koyi oblasti za 2019 r.]. Part 1 / Ed. Svetlana Zimovina. Lviv, $310 \mathrm{p}$.

8. Shulskyi M.G. (2020). Analysis of the ratio of livestock and livestock production by farms in the Lviv region at the turn of the century [Analiz spivvidnoshennya poholiv"ya sil's'kohospodars'kykh tvaryn i vyrobnytstvo tvarynnyts'koyi produktsiyi hospodarstvamy L'vivshchyny na styku epokh]. Scientific Bulletin of Lviv National University of Veterinary Medicine and Biotechnology named after S.Z. Gzycki. Economic Sciences Series, vol. 22, no. 95. Lviv, pp. 32-37.

9. Shulskyi M.G. (2017). Agricultural production in the spheres of crop production and the junction of epochs: past, present, future [Ahrarne vyrobnytstvo u sferakh roslynnytstva ta styku epokh: mynule, suchasne, maybutnye]. Journal of Kyiv University of Market Relations "Business Economics, Administration, Law", issue 3, pp. 183-201.

10. Shulskyi M.G. (2017). Analysis of the level of profitability of agricultural production in agricultural enterprises of Lviv region [Analiz rivnya rentabel'nosti ahrarnoho vyrobnytstva $v$ sil's'kohospodars'kykh pidpryyemstvakh L'vivshchyny]. Applied economics - from theory to practice: materials of the International scientific-practical conference. Ternopil: FOP Osadtsa Yu.V., 284 p. P. 172-175. 